Laura Putri Sindangsari ${ }^{1}$, Moses Glorino Rumambo Pandin ${ }^{2}$

Airlangga University

Airlangga Street No. 4-6, Airlangga, Gubeng Districs, Surabaya City, East Java 60115

laura.putri.sindangsari-2020@fib.unair.ac.id; moses.glorino@ fib.unair.ac.id

\title{
BOOK REVIEW : \\ THE CONTRIBUTION SERIES OF PSYCHOLOGICAL THINKING FOR THE NATION 4: PSYCHOLOGY AND NATIONAL INTEGRATION \\ (SERI SUMBANGAN PEMIKIRAN PSIKOLOGI UNTUK BANGSA 4: PSIKOLOGI DAN INTEGRASI BANGSA)
}

Clara R. P Ajisuksmo, dkk; Jakarta; 2020; 978-602-96634-9-5; 473 pages

Indonesia is a country that consists of differences in ethnicity, language, customs, and skin color. This diversity can cause conflict and division, both caused by internal problems or external problems, so national unity is needed to maintain the integrity of the nation and prosper the people. Therefore, this book, which contains the thoughts of psychologists, was created as a contribution from psychologists in maintaining the unity and integrity of the nation.

The book contents are 27 articles from 38 authors. It is a collection of the thoughts of psychologists on the issue of national integration. Their thoughts can be used by college students to add insight and train their thinking in solving various problems of the nation. In addition, It is also expected to inspire power holders and various parties in finding solutions and answering national problems related to the themes.

According to the title, the writer explains the nation's problems in Indonesia using psychological studies. As we know, Indonesia often has conflicts that can threaten the unity of the nation. Indonesia causes this has a variety of diversity so that the potential for conflict can occur at any time. Therefore, the author tries to give his thoughts to solve the problems in Indonesia through a psychological view.

"The Contribution of Psychological Thought to the Nation 4: Psychology and Nation Integration Series" needs to be reviewed to provide a reviewer's understanding of the book's topics, strengths, and weaknesses based on the reviewer's views. In addition, It is made to invite readers to think and reflect on the thoughts of the psychologists. Thus, readers can consider it to be read further as an appropriate reference or guide in solving problems related to national integration.

The writers' thoughts in the book are explained in detail and completely. It also includes the basics of their thoughts. It greatly fulfills the needs of college students, power holders, and various other parties in finding solutions to solve problems related to the integration of the Indonesian nation. The thoughts did not appear suddenly, but it appeared as developed the thoughts of other figures such as Mosco, Peter Golding, and others related to the conflicts being analyzed.

The latest information from this book is how the author analyzes and views the problem of Indonesian diversity using psychological studies. Indonesia is a country that has a variety of diversity; ethnicity, language, region, religion, skin color, customs, and sharing perspectives. At the belief system level, all Indonesian citizens are aware that Indonesia has a variety of diversity that has been introduced for a long time with the concept of "Bhinneka Tunggal Ika". Sadly, this diversity cannot be separated from the problem. Friction and clashes between different groups based on ethnicity, region, religion, or interest often adorn the mass media. This shows that the concept of "Bhinneka Tunggal Ika", which has become a belief system, is often forgotten. This is in line with the scheme proposed by Fisbhen \& Ajzen (2005). It is The Theory of Reasoned Action / Theory of planned behavior. This theory explains that the existing 
belief system will affect attitudes, subjective norms, and control of individual behavior. These three things will strengthen a person's intention or intention to do things that are believed and felt true. When forgetting about the belief system occurs, the behavior will become out of sync. The author relates this theory to diversity in Indonesia. If the belief system is still deeply rooted in citizens' citizens, national integration will be realized.

To overcome the problems in diversity, the author uses psychological studies to see diversity in dealing with diverse social environments. Psychological studies are the science of studying and considering how individuals think and behave. Diversity is constructed socially, and this construction affects the identity and behavior of individuals (Blaine, 2012), as described in the Psychology of Diversity if there is a racial conflict that arises from diversity, the basis for examining the conflict not through differences but through Indonesian people's way to construct this diversity.

The author views that one of the keys that are considered to reduce the possibility of a shift in society due to differences and diversity is a positive perception of multiculturalism. Individuals in society can develop positive perceptions about multiculturalism through education in educational institutions and families that emphasize diversity. Diversity-based education can be done from an early age in children. The learning process by people can be accompanied by actual content and examples that support the teaching. The positive consequence of education that is friendly to difference and diversity is encouraging individuals to engage and interact directly with other people who are not from the group to help reduce prejudice through these positive experiences.

The author tries to analyze the national integration problem in diversity in Indonesia through psychological studies. Conflict can occur due to the involvement of human behavior. Through psychology, readers understand that psychological studies can also be applied to analyze various problems in Indonesia.

The influence is that readers become more critical in looking at these issues and knowing how to address them. Cases that threaten national integration will always exist, and the methods used will always differ over time. Therefore, it can train readers in analyzing the cases contained in this book. The readers also know the author's way of criticizing and overcome these problems. As a result, readers can become accustomed to analyzing new cases and contributing to their thoughts to solve them.

In the book content, the authors only provide a few specific pieces of conflict evidence because the conflict evidence provided is described in general, such as political conflicts, elections, and racial conflicts. However, there is a conflict where the case is explained more specifically. It is the case of local sons and immigrants in Papua, which arises because of social construction.

The conflict evidence is true in Indonesia if the reader knows that conflict from in the news. Unfortunately, people who have never heard of this conflict will feel that the truth is confined. The author only states that this conflict occurred several years ago without giving a specific time for the conflict. As a result, readers have to search the internet for information on the conflict to ensure that the conflict happened in Indonesia.

This conflict occurred due to the declaration of the Papua program as a transmigration destination, which the traditional elders in Papua rejected. This rejection is based on the experience of the transmigration program during the New Order era. In that era, a lot of forest land was cleared, and the employment of local peoples was limited because transmigrants had more competence than local people. The authors conclude that the social construction has made immigrants being considered colonizers. After analyzing, the author's view on this problem is that officials should provide guidance and information that the transmigrants come as brothers who will pay attention to customary rights, teach skills, and teach knowledge. Thus, the social construction of newcomers will be different. This case can be found on page 161 . 
The contents of the book are 27 articles with different titles. The contents are well organized. The placement of the articles is adjusted to the theme of each chapter. Each article in the chapter also can be connected so that they complement each other. It consists of 473 pages, so the book looks quite thick.

There is no studies, facts, or ideas that the author of the book ignored. The problems presented by the author are under the facts though these problems are discussed in general terms. In analyzing, the studies that psychologists use are also mentioned to support the psychologists' explanation in describing their thinking. Thus, the studies, facts, or ideas conveyed by the author are very clear because these aspects are interrelated in their explanation.

This book is worth reading because the cover used fits perfectly with the topics discussed. The cover is a picture of three hands with different skin tones holding on to one another. It reflects the nation's integration in diversity. Moreover, the language is very polite. The reference sources are also mentioned completely, and citations accompany the inclusion of thoughts from other characters.

However, It has several shortcomings. The language used is too formal, so it seems awkward and easy to get bored when reading for a long time. The problems that occur also have no specific time and location of the conflict. In addition, there are several typing errors.

Writers need to include in more detail the location and time of conflict. Although the author reveals the conflicts that often occur in Indonesia, it would be better if the conflicts discussed to be more specific. As a result, readers can make comparisons between conflicts in the same scope. In addition, the writers need to pay attention to using the words used so that there is an integration between the words in a sentence. Also, the writers should pay attention in choosing words so that they are not too stiff and the readers can read comfortably and do not get bored easily.

Laura Putri Sindangsari and Moses Glorino Rumambo Pandin Airlangga University

\section{REFERENCES}

Ajisuksmo, Clara R.P. dkk. (2020). Seri Sumbangan Pemikiran Psikologi Untuk Bangsa 4: Psikologi dan Integrasi Bangsa. Jakarta: Himpunan Psikologi Indonesia (HIMPSI).

\section{AUTHORS:}

1. Clara R. P Ajisuksmo. She is a researcher and currently serves as head of the community development studies center and lecturer at the Faculty of Psychology at the Atma Jaya Catholic University of Indonesia. She completed his S1 at the Faculty of Psychology, Gajah Mada University, Yogyakarta; Master of Science (MSc) at the School of Education, State University of New York (SUNY) at Albany, New York, USA; and doctorate (Ph.D.) at the University of Tilburg, The Netherlands. From 2009 until now, She has been a resource person for developing noble moral education at the Ministry of Education and Culture.

2. Abd Ala. He was born in a small village in Sumenep District on September 5, 1957. Primary and secondary education was completed at Madrasah An-Nuqayah, Gulukguluk, Sumenep. He continued his undergraduate degree at the Faculty of Adab, IAIN. The master's and doctoral degrees were won from IAIN Syarif Hidayatullah, Jakarta. In addition to conducting various researches and being a resource person in academic activities, seminars, or national and international conferences, he is also 
concerned and actively involved in resolving socio-religious conflicts in the country, such as as a consultant and an advisor to the consortium of justice and peace (KK) Malang (2002 -now).

3. Ilham Nur Alfian. He was born in Surabaya in 1976. He is a Lecturer at the Department of Personality and Social Psychology, Faculty of Psychology, Airlangga University. He is also an alumnus of the Professional Psychology Masters Program with a Specialization in Clinical Psychology at the Faculty of Psychology, Airlangga University. Currently, he is the chairman of the Indonesian Psychological Association (HIPAA) for the East Java region (2019-2023).

4. Nisa Rachmah Nur Anganthi. She is s lecturer who focuses on Forensic and Clinical Psychology, especially those related to the psycho-spiritual dimension. Before getting her master's degree (1998) and doctorate (2010) at the Faculty of Psychology in Gajah Mada University, She earned a bachelor's degree in psychology at Airlangga University (1991). She started teaching at the Faculty of Psychology, the University of Muhammadiyah Surakarta, in 1994 until now. She has been an expert guest lecturer at the Psychology study program at the University of Muhammadiyah East Kalimantan (UMKT) Samarinda since 2017.

5. Fitria Eka Annisa. She was born in Padang on March 26, 1993. She is a Masters in Developmental Psychology, graduated from the Faculty of Psychology at Gajah Mada University. She became a lecturer assistant at Spikes Iris Padang (2018). She has attended several national seminars on both popular and practical psychology.

6. Yulia Hairina. She was born in Banjarmasin on March 18, 1984. She studied undergraduate psychology at the University of Muhammadiyah Malang (2016) and mastered the psychology profession at the Islamic University of Indonesia (2010). She is a permanent lecturer in the Islamic Psychology study program at UIN Antasari Banjarmasin.

7. Penny Handayani. She is an Undergraduate (2005) and master's (2008) from the Faculty of Psychology, University of Indonesia. She is a teaching staff in the Psychology section of the Faculty of Psychology, UNIKA Atmajaya. Her interest in the psychology of children with special needs encouraged her to do many teaching, research, and community service in that area.

8. Ike Herdiana. She was born in Bandung on May 22, 1975. She completed her undergraduate education as a psychologist and a master's degree in psychology at the Faculty of Psychology, Padjadjaran University, Bandung. Currently, she is a teaching staff at the Department of Personality and Social Psychology, Faculty of Psychology, Airlangga University, Surabaya.

9. Adi Heryadi. He is the teaching staff of the psychology study program, Faculty of Economics and Social Unjani Yogyakarta was born in Singkawang (West Kalimantan) on December 16, 1976. He graduated from 1 Pontianak High School, S1 and S2, at the Faculty of Psychology, Islamic University of Indonesia (UII) Yogyakarta.

10. Inge Hutagalung. She holds a doctorate in Communication from the Faculty of Social and Political Sciences, University of Indonesia (2002); Bachelor of Science in Mass Communication from FISIP, University of Indonesia (1982). She is a permanent 
lecturer in the postgraduate master's program of Communication Science at Mercu Buana University.

11. Imadduddin. He was born in Banjarmasin on September 25, 1982. He studied undergraduate psychology at the Faculty of Psychology, University of Muhammadiyah Malang (2006); Masters in Psychology at the Faculty of Psychology, Gajah Mada University, Yogyakarta (2008). He is now a permanent lecturer in the Islamic psychology study program, Ushuluddin Faculty, and Humanities UIN Antasari Banjarmasin.

12. Bayu Jatmiko. He was born in Denpasar on October 13, 1983. He studied at SD Swastiastu, Denpasar; Notre Dame Elementary School, Jakarta; 57 Senior High School Jakarta; Faculty of mechanical engineering at Brawijaya University, Malang, but did not graduate. Finally, He continued his studies until graduating from the Faculty of Psychology, University of Mercu Buana, Jakarta. He is active as an assistant lecturer for Dr. Inneke Limuria, M.Si, since 2008 until now.

13. Meike Kurniawan. She was born in Probolinggo on May 9, 1981. She graduated with a bachelor of psychology at the University of Surabaya (UBAYA); Master of management (Marketing) at Trisakti University, Jakarta. She is a permanent lecturer at the Faculty of Psychology, Tarumanegara University, Jakarta.

14. Rahmatsyam Lakoro. $\mathrm{He}$ is a teaching staff at the Department of Visual Communication Design, Sepuluh November Institute, Surabaya. He was born in Poso on September 7, 1976. He studied Visual Communication Design at the Bandung Institute of Technology (1994-1999); education S2 Game Technology in Electrical Engineering, Ten November Institute (2007-2009).

15. Amy Mardhatillah. She is a doctorate in industrial and organizational psychology. She was born on August 8, 1984. Amy completed her undergraduate, postgraduate and doctoral programs at the psychology faculty of International Islamic University Malaysia in Kuala Lumpur. She currently serves as deputy dean of the psychology faculty at Mercu Buana University, Jakarta.

16. Clara Monika. She is s graduate of the psychology doctoral program from Gunadarma University, Jakarta. She has worked as a lecturer since 2002 and has taught at various universities in Jakarta. Since 2017, she has been a permanent lecturer at Pembangunan Jaya University.

17. Rifqi Muhammad. He was born in Ledo on October 14, 1990. He graduated from SDN 14 Sejangkung (2002); MTs Yasti Sekuduk (2005); MAS PPMBI (2008); S1 STAI Sultan Muhammad Syaifuddin Sambas (2012), and S2 BKI UIN Sunan Kalijaga Yogyakarta (2016). He is a Lecturer at IAI Sultan Muhammad Syaifuddin Sambas (2016-present).

18. Rini Nurahaju. She was born in Jember 1968. She completed her Bachelor of Psychology study at Airlangga University (1994), Masters in PSDM at Airlangga University Postgraduate, Doctoral specialization in Organizational, industrial psychology at Airlangga University (2017). Currently, she is working as a lecturer at the psychology faculty at Hang Tuah University, Surabaya. 
19. Nicolas Indra Nurpatria. He is the first batch in the psychology faculty of Atma Jaya University, Jakarta. He completed his bachelor's degree in 2000 and continued his psychology education at the same university. In 2010, he continued his education in the psychology master program at the psychology faculty of the University of Indonesia, apart from being a part-time lecturer at the psychology faculty of Atma Jaya Unika, Jakarta. He has also worked as one involved in mentoring young people, educators, and parents since students until now.

20. Indah Andika Octavia. She was born in Jakarta on October 16, 1993. She graduated from the master's program in developmental psychology, Faculty of Psychology, Gajah Mada University. She became a lecturer assistant at Spikes Iris Padang (2018). She has participated in a national seminar on the topic of psychology.

21. Ira Puspitawati. She is the Head of the Gundarma University Faculty of Psychology undergraduate study program. She graduated from S1 Psychology Education, Gajah Mada University (1995); Masters in Psychology, Indonesia University (2004); S3 Psychology, Universite De Bourgogne, France (2011). The subjects taught are cognitive psychology, psychology, and the internet, psychological information systems, cyberpsychology.

22. Wahyu Rahardjo. Chairman of the Center for Cyberpsychology Studies, Gunadarma University. He graduated from S1 Psychology, Gunadarma University (2002); Masters in psychology, Gunadarma University (2006); S1 Psychology, Gajah Mada University (2013). The subjects taught are quantitative research methodology, psychological scale preparation, measuring instrument construction, cognitive psychology.

23. Lucia R.M Royanto. She currently serves as head of the undergraduate psychology study program, Faculty of Psychology, University of Indonesia. She completed her Bachelor of Psychology at the University of Indonesia; Masters in educational psychology, Faculty of Postgraduate, University of Indonesia; Master of Special Education, Faculty of Education, University of Newcastle, Australia; doctorate in psychology, University of Indonesia.

24. Shahnaz Safitri. She is a Teaching staff at the faculty of psychology, University of Indonesia. She was born in Medan in 1994. She completed her undergraduate studies at the psychology faculty of the University of Indonesia (2014); master of psychology profession at the University of Indonesia in Educational Psychology (2017). Her research interest is to explore affective factors that support thought processes and create and measure instrument construction.

25. Ermida Simanjutak. She was born in Surabaya in 1977. She completed her undergraduate studies at the psychology faculty, Airlangga University (2000); S2 education at the University of Groningen, Netherlands (2005) in the field of educational effectiveness and school improvement; master of professional psychology in the field of educational psychology at Airlangga University (2015). Currently, she works as a teaching staff at the psychology faculty of Widya Mandala Catholic University, Surabaya.

26. Gita Widya Laksmini Soerjoatmodjo. She was born in Jakarta on September 11, 1976. she studied undergraduate psychology at the University of Indonesia (1994- 
1999); Masters in understanding and securing human rights at the School of Advanced Studies, Institute of Commonwealth Studies, University of London, England, with a Chevening Award scholarship; S2 psychologist professional program in the field of educational psychology, University of Indonesia (2008-2010). she is a lecturer at the Faculty of Psychology, Pembangunan Jaya University (2011-present).

27. M. Arief Sumantri. He was born in Kendari City, Southeast Sulawesi. He graduated with a degree in criminal law at Halu Oleo University (2015); special education for the PERADI advocate profession at Wijaya Kusuma University (2018); Master of Psychology at Airlangga University (2019). Since 2018, he has been part of the "hallo Jiwa Indonesia" family that actively promotes mental health in the community and is registered as a member of the Social Psychology Association (2019).

28. Sumaryono. Currently. he is a lecturer who focuses on industrial and organizational psychology at the faculty of psychology, Gajah Mada University. He formulated the concept of "career performance" in millennial work activities and often discussed the development of generations $\mathrm{Y}$ and $\mathrm{Z}$ from various perspectives and consequences.

29. Christianity Suwartono. She completed his undergraduate education majoring in Psychology (2001) at the University of Indonesia (FP UI); Education Master in Psychometric (2005) at FP UI as well as a teaching assistant, and also works in the technical documentation section of an IT company. After graduating, she joined as a permanent lecturer at the psychology faculty, Atma Jaya Indonesia Catholic University (UAJ).

30. Agus Suwignyo. He is a lecturer at the Department of History, Faculty of Cultural Sciences, Gajah Mada University. He obtained a bachelor's degree in English education at Sanata Dharma University in 1997; master of arts in educational sciences at the University of Amsterdam in 2011; doctorate in history at Leiden University in 2012.

31. Jessie Janny Thenarianto. is Alumna, Faculty of Psychology, Ciputra University, Surabaya. she has interests in forensic psychology, youth, and digital activism. Her latest research discusses the role of individual and relational factors in predicting the psychological well-being of Instagram users.

32. Harijanto Tjahjono. He is a lecturer at the psychology faculty, University of Surabaya. He completed his bachelor's degree in psychology faculty at the University of Surabaya; Master and doctoral education completed at the Human Resource Education Program, Boston University. He is the author of book chapters entitled "Psychology and diversity" and "There are me between China and Indonesia".

33. Harini Tunjungsari. She holds a bachelor's degree in Psychology (2000) and a Master's in Professional Psychology in Education (2004) from the University of Indonesia. she is a teaching staff in the educational psychology section of Atma Jaya University, Jakarta. Currently, she is pursuing further education at the doctoral study program in psychology at the University of Indonesia.

34. Ahmad Naufalul. He completed his undergraduate studies at the University of Indonesia and the University Of Queensland, Master of Science in Social Psychology, the University of Indonesia, with a thesis on belief in conspiracy theories. Currently, 
He is active as a lecturer and student advisor in the psychology faculty of Mercu Buana University.

35. Josefina Marijke. is a lecturer at the Faculty of Medicine, Universitas Cendrawasih Jayapura Papua. she is also chairman of the Papua region HIMPSI for the period 20082020. she obtained a bachelor's degree in psychology from the faculty of psychology UNTAG Surabaya (1995); master of clinical psychology from Airlangga University, Surabaya (2005); a doctoral candidate in psychology at Airlangga University.

36. Jony Eko Yulianto. He is a Lecturer in social psychology and qualitative research methods at the Faculty of Psychology, Ciputra University, Surabaya. Currently in Auckland for a doctorate in social psychology at Massey University. Currently, he is developing a research interest in inter-group behavior by linking the political situation at the national level and the life of daily marital relations.

37. Livia Yuliawat. has been a lecturer at the psychology faculty, Ciputra University, since 2008. She completed his doctoral studies at The University of Hong Kong in the field of psychology of religion. She teaches subjects related to personal development, career development, and research methods.

38. Desni Yuniarni. She was born in Pontianak in December 1979. He currently teaches at the faculty of teacher training and education, Tanjungpura University, Pontianak. She provided much education to the community through seminars, training, and writing in popular media about early childhood education and development. 